\title{
Teacher Competency in Competency-Focused Science Teaching in the South Korean Context: Teacher Self-Assessment Instrument Development and Application
}

\author{
Nam-Hwa Kang \\ Corresponding author, \\ Physics Education Department, Korea National University of Education, \\ Cheongju-si, Chungbuk, Korea 28173 \\ nama.kang@gmail.com \\ Hunsik Kang \\ Graduate School, Seoul National University of Education, \\ Seocho-gu, Seoul, Korea o6639 \\ kanghs@snue.ac.kr \\ Seungho Maeng \\ Science Education Department, Seoul National University of Education, \\ Seocho-gu, Seoul, Korea o6639 \\ smaeng@snue.ac.kr \\ Jongwon Park \\ Physics Education Department, Chonnam National University, \\ Gwangju, Korea 61186 \\ jwpark94@jnu.ac.kr

\section{EunyoungJeong} \\ Biology Education Department, Chonnam National University, \\ Gwangju, Korea 61186 \\ jey@chonnam.ac.kr
}

Received: 18 October 2020 | Revised: 2 November 2020 |

Accepted: 19 November 2020 


\begin{abstract}
The purpose of this study was to examine teachers' competency in teaching for student competence in science. Drawing on literature on competence and science teacher education, we identified 44 indicators of science teaching competence in relation to the current Korean National Science Curriculum, from which 54 items for teachers' self-assessment were developed and validated. Through online administration of the self-assessment instrument, responses from 210 primary and secondary teachers were collected. Factor analysis resulted in nine factors across three competence areas. Teacher competence differed across factors. One-way ANOvA analysis revealed that primary teachers indicated significantly higher competence in most aspects of teaching than secondary teachers and that years of teaching was related to professional development methods utilized by teachers. Suggestions for professional development program design and further research topics were discussed.
\end{abstract}

\title{
초록
}

이 연구의 목적은 과학역량수업에 대한 교사의 역량을 조사하는 것이다. 역량과 과 학 교사교육에 관한 문헌을 토대로 한국의 과학교육과정과 연관된 과학수업역량 지표를 추출하고, 전문가 검증을 거쳐 총 44 개의 역량지표를 도출하였다. 이 역량 지표로부터 현장교사의 자문과 검증을 통해 54항목의 역량수업을 위한 과학수업 역량 자체평가표를 구성하였다. 온라인 자체평가실시를 통해 210 명의 초, 중등 교 사 응답을 수집하여 분석하였다. 요인분석결과 3 개 영역에서 9 개의 요인이 밝혀 졌고, 일원분산분석 결과 초등교사의 역량이 대부분의 측면에서 중등교사보다 유 의하게 높은 것으로 드러났고, 교사의 경력은 전문성 개발 방법의 측면에서만 유 의한 차이를 보였다. 교사의 전문성 개발의 방향과 추후 연구 주제를 제안하였다.

\section{Keywords}

science teaching competency - competency-based teaching - professional competence - teacher self-evaluation

\section{Introduction}

At the turn of this century, educational communities across the world proposed educational reform agendas to meet the new demands of preparing future citizens for literacy in the 21st century. The reform agendas encompassed social 
constructivist teaching and learning that promotes learners making meaning in collaboration with others and actively participating in learning activities as independent thinkers (Windschitl, 2002). Also, educational goals transcend knowledge acquisition by including competence that encompasses knowledge, skills, and affective facets necessary to live in the current global knowledge society (OECD, 2005). For this reform to be successful, teachers are required to play a substantially different role (Putney \& Broughton, 2011). Thus, teachers' professional competency required by the reform agenda is crucial, and understanding the required teacher competency is critical for teacher education and professional development (PD; Caena, 2014). This entails understanding reform frameworks, developing tools for teacher evaluation, and generating possible methods for teachers' professional learning. Moreover, modeling the structure of teacher competency in various contexts is regarded as essential for advancing theories of teacher education (Guerriero, 2017; Kaiser, Blömeke, König, Busse, Döhrmann, \& Hoth, 2017; Kunter, Klusmann, Baumert, Richter, Voss, \& Hachfeld., 2013; Seidel \& Sturmer, 2014).

Competency is defined as capability of a person to perform a task to reach specific goals (Alake-Tuenter, Biemans, Tobi, Wals, Oosterheert, \& Mulder, 2012). Personal competency can be distinguished from the typical notion of ability in that it denotes integrated capabilities that can be shown during task performance. Thus, it consists of cognitive, psychomotor, and affective aspects that are amalgamated in task performance. Furthermore, the concept of teacher competency is contextualized from various social and cultural perspectives on education. Researchers have made some effort to find common ground for teacher competency across different cultural traditions (Blömeke \& Kaiser, 2017; Caena, 2014; OECD, 2013). In terms of the nature of teacher competency, researchers seem to agree that teacher competency is multidimensional and dynamic rather than any stable state of knowledge and skills (Blömeke, Gustafsson, \& Shavelson, 2015). Thus, because it is definitely educable and developmental, assessing teacher competency is crucial for teacher education and PD.

In general, competency is deemed to consist of three broad categories of elements: knowledge, skills, and dispositions to perform tasks (McDiarmid \& Clevenger-Bright, 2008). Among these three elements, teacher knowledge has been researched extensively in both teacher education and PD. Following Shulman (1987), teacher knowledge has been divided into various types such as subject matter knowledge, pedagogical content knowledge, general pedagogical knowledge, curriculum knowledge, and so on. Each of these types of knowledge is further divided into subcategories (Kind, 2009). Teacher skills include a variety of psychomotor skills such as organizing and orchestrating instruction; 
using instructional materials and technology; managing groups; collaborating with colleagues, parents, and the community; and so on. Dispositions include beliefs, attitudes, values, and commitments (McDiarmid \& Clevenger-Bright, 2008). Knowledge and skills are often called what teachers should know and be able to do, while dispositions have been shown to mediate teaching practices (Pajares, 1992; Kang \& Wallace, 2005). Such a relationship among the elements of competency could be interpreted differently. For example, Blömeke et al. (2015) suggest that cognitive and affective teacher characters are mediated by situation-specific skills to generate observable performance behaviors. Their model connects the three elements of teacher competency by positioning knowledge and dispositions as the basis of competence and skills as mediating factors between knowledge and performance. These different perspectives on how elements of competency are related to each other need further research. Nonetheless researchers agree that the three types of elements are integrated in some way or another and manifest in task performance.

From the perspective that teaching is a practice mediated by sociocultural contexts, the content of teacher competency is expected to vary across different social contexts, including place and time. Thus, teacher competency defined in one context may differ from that in another context. In other words, teacher competency reflects the contemporary socio-historical circumstances in which teachers work (McDiarmid \& Clevenger-Bright, 2008). This is why the recent resurgence of teacher competency research should be distinguished from teacher competency research conducted in 1970s that was based on the notion of teacher effectiveness (Gonczi, 1994). The nature of teachers' work has changed a great deal (Brante, 2009), and the current view of competency is nested in a sociocultural constructivist view of teaching and learning.

Related to the view of teaching as socio-culturally mediated practice is the situated learning perspective (Lave \& Wenger, 1991). From this view, teachers develop not only as individual practitioners, but also as members of local communities of practice. Just as teaching is socially mediated and contextually situated, teacher actions, even when they are away from colleagues, contribute to a particular school culture and educational climate as much as they are shaped by them. Thus, teacher competency should be understood from their practices in concrete situations, rather than in their abstract knowledge or cognitive processes. In the same vein, teacher competency should encompass teachers' ability to jointly build and participate in communities of practice with a critical or reflective stance for their PD (McLaughlin \& Talbert, 2001). These elements of professional knowledge, skills, dispositions, and communal practices for development are what Shulman (1998) identified as defining features of professions, including "calling" for service, theoretical understandings, skilled 
practices, professional judgement, experiential learning, and self-monitoring community.

In South Korea, the National Science Curriculum was revised in 2015, and the curriculum emphasis was shifted from cognitive to competence goals. The curriculum presented five core competencies in science that should be developed in primary and secondary school science classes (Korean Ministry of Education, 2015). Following the competency-focused curriculum reform, there has been a call for guidelines in science teacher PD that could show the kind of teaching competency required for successful teaching for core competence in science. This study was initiated by the call to develop a self-assessment instrument for in-service teachers to use in reflecting on their teaching competency focusing on teaching for core competence in science. We developed and administered a teacher self-assessment instrument and then examined teachers' perceptions of their science teaching competency to draw implications for designing PD programs in teaching for science competency. In doing so, this study would inform designing of PD for competency-based teaching.

Competency-driven teacher education has a long history (Gonczi, 1994) in which what teachers should know and be able to do in the exercise of their profession have been delineated in various ways. The complexity of teaching has been well recognized. As such there has been a great deal of effort to figure out a framework for understanding such a complex endeavour. Danielson (2007) identifies 22 essential aspects of teachers' responsibilities that have been documented through research. These essential components include demonstrating knowledge of content and pedagogy, designing coherent instruction, creating an environment of respect and rapport, managing student behavior, communicating with students, and growing and developing professionally, to name a few. These 22 components are grouped into four domains: planning and preparation, the classroom environment, teaching, and professional responsibilities. This framework addresses teaching comprehensively, while Vogt and Rogalla (2009) identified four areas of teaching competency focusing on teachers' ability to foster students' conceptual learning and motivation in science. The four areas include subject matter knowledge, understanding of learning processes and diagnosis of student learning, knowledge of teaching methods, and classroom management. This framework was informed by research on pedagogical content knowledge (Shulman, 1987). In terms of subject-specific teaching competency, a number of recent studies examined mathematics 
teaching competency (e.g., Kaiser et al., 2017). Also, research on inquiry-based science teaching competency at the primary school level can be found (AlakeTuenter et al., 2013).

In creating a teacher competency framework, there can be a number of assumptions on which competency for successful teaching is defined (Blömeke, Gustafsson, \& Shavelson, 2015). Generally, successful teaching is defined in terms of teachers' ability to plan and implement instructions to help students achieve specific pedagogical goals and objectives and assess the results of teaching to improve their impact. Under this general notion of successful teaching, Danielson (2007) defined teaching competency in terms of highlevel learning goals for students, deep and flexible understanding of complex content, constructivist approaches to teaching, purposeful teaching for meaningful learning, and teaching as professional work. Similarly, Alake-Tuenter et al. (2013) identified inquiry-based science teaching competency for primary school teachers based on constructivist teaching and learning. Through a Delphi study, they developed an inquiry-based science teaching competency profile that includes three broad categories: content knowledge, pedagogical content knowledge, and attitudes. Given that the existing literature on science teachers mostly focuses on teacher knowledge, attitudes as a stand-alone category in Alake-Tuenter et al's study is worth attention. In particular, subcategories of attitudes such as attitudes toward science and science education, attitudes toward themselves as science teachers, as well as science teaching competency development, are noteworthy. Given the nature of a Delphi study, the attitudes category reflects expert science teacher educators' belief that knowledge alone is not enough to ensure competent science teaching.

In the literature, however, competency in action, in other words, competency observed in teaching practices, has been addressed less frequently. Vogt and Rogalla (2009) examined the effect of coaching on adaptive science teaching competence through a writing instrument. To assess teachers' planning competence, they used teachers' responses to a vignette. To assess implementation, they used a video clip in which a teacher misses an aspect of competent teaching that might call for comments by the viewer. Whereas these two methods are useful in probing teachers' knowledge activated by specific teaching contexts, they are disadvantageous in examining competence in practice. Teaching practices observed and coached during intervention processes in the study revealed that an important aspect of competency aimed at in the study, in other words, adaptive teaching, was neglected in implementation (Vogt \& Rogalla, 2009, p. 1053), but the instrument failed to expose that clearly. Given that the notion of competency highlights teachers' capability to implement knowledge and skills with proper dispositions, it is unfortunate that teacher 
enactment is less discussed in the literature on teacher competence. As far as teaching competency is defined as the ability to practice "successful" instruction, teaching performance should be assessed with appropriate methods (Gonczi, 1994).

Research on teaching practices has focused on aspects of teachers' cognition such as knowledge and beliefs (Fang, 1996; Kulgemeyer, Riese, 2018; Voet, \& De Wever, 2016). In particular, teachers' pedagogical content knowledge and beliefs related to classroom teaching have been researched a great deal (Chan \& Hume, 2019; Depaepe, Verschaffel, \& Kelchtermans, 2013; Gess-Newsome, Taylor, Carlson, Gardner, Wilson, \& Stuhlsatz, 2019). In these studies, teaching practices have been examined to determine whether teachers put into practice their knowledge and beliefs and factors that foster or hinder in the process. These studies provide cognitive components of teacher competency, while motivational orientations and attitudes as professionals are left out (Sorge, Stender, \& Neumann, 2019). Furthermore, most research on teacher knowledge and practices so far has focused on students' cognitive learning rather than the competence development that has recently been emphasized in schools (Rychen \& Salganik, 2001). Teachers are expected to provide learning opportunities that support students in developing 21st century competency in general and core competency of domains such as science. Therefore, teacher competency for competency-driven school education should be delineated to inform teacher PD for such learning goals.

\subsection{Context of South Korea}

In South Korea, teacher licenses, approved by the Ministry of Education, are awarded upon completion of teacher education programs, mostly at the undergraduate level. Teacher education programs for each type of license have similar coursework requirements for licensure. For example, science teacher licenses for secondary school are awarded in five areas: physics, chemistry, life science, earth science, and integrated science. By requiring about $50 \%$ of undergraduate degree credits in areas such as subject matter, pedagogical content (e.g., science teaching methods), and general pedagogy, most programs apply similar standards to licensure. Also, a common public-school teacher employment examination for each license area administered once a year aligns teacher preparation program content to some degree (Kang, 2013).

In South Korea, the teaching profession has been so popular that high achieving students (up to the top $15 \%$ of high school students) have been enrolling in teacher preparation programs at the undergraduate level. Public 
school teacher employment examinations are also very competitive (Kang \& Hong, 2008). However, the initial licensure and examination-based teacher quality assurance has not been followed up with encouragement or support for teachers' continual development. Teachers are tenured upon employment and then have little encouragement to develop their teaching competency further. This issue has been discussed for more than a decade, initiating requirements such as 60 hours of PD every 5 years in recent years (Kang, 2017). In addition, various policies to promote teacher PD through teacher learning communities and master teacher positions for peer coaching have recently been instituted (Kang, 2013).

Currently, most schools in South Korea have instituted teacher evaluation for professional development (TEPD) as one requirement of teaching. Teachers self-assess their PD needs using evaluation instruments they develop themselves based on a framework and a sample instrument provided by the Ministry of Education (Kang, 2013). The self-evaluation framework for classroom teachers consists of two areas: academic instruction and student advising. The academic instruction area consists of three elements, lesson preparation, lesson implementation, and assessment, which have 12 evaluation criteria in total. Examples of items for evaluation include "analyze subject matter carefully and plan lessons based on student capacity," "engage students for active participation," and "demonstrate a passion in instructional activities," to name a few (Kang, 2013). The self-evaluation is complemented by peer observations of teaching using the same evaluation tool and surveys taken by students and parents concerning their satisfaction with lessons. Based on the formal selfevaluation, teachers submit their PD plans, while schools and school districts provide PD programs based on teachers' PD plans. Such a formal teacher evaluation policy has continued for a decade so far, although its limitations have been observed and it has received criticisms. One of these criticisms is its lack of discipline-specific evaluation, lacking specific feedback on teachers' classroom teaching (Han \& Yoon, 2012). The current self-evaluation process is too general to provide feedback that will help teachers to come up with specific ideas of what they should develop further. Furthermore, with recent revisions to the curriculum, the evaluation of teachers' classroom teaching needs to be modified if the curriculum reform is to be successful.

\subsection{Approaches to Profiling Teacher Competency}

With regard to discipline-specific competency, Alake-Tuenter et al's (2012, 2013) project informed this study. They identified science teaching competency 
at the primary school level. The premise of successful science teaching in their study was inquiry-based science that could be broadly described as constructivist, in which students identify their inquiry problems, solve the problems on their own and communicate their solutions with scientific evidence. In the process, the teachers' role was conceptualized as preparing science lessons based on proper subject matter knowledge, asking questions, stimulating scientific discourse, connecting students' prior knowledge to new (scientific) knowledge, and so on. The resulting science teacher competency profile consisted of three components: subject matter knowledge, pedagogical content knowledge (PCK), and attitudes. In their study, they conceptualized PCK as an indicator of teacher skills to match with the typical elements of competence: knowledge, skills, and dispositions. The science teaching competency profile is normative in a sense that it is what the literature and experts expect primary teachers to hold in order to perform inquiry-based science lessons. These elements are, however, not necessarily connected to teaching practices because they may not be activated in teaching for various reasons.

In contrast to the normative search for teacher competency in terms of cognition, Marshall, Smart, and Alston (2016) employed an observational tool to identify aspects of successful teaching for student learning. These aspects include (a) providing coherent and connected learning, (b) using instructional strategies and resources to engage students, (c) providing a safe and respectful learning environment, (d) providing challenging rigorous learning opportunities, (e) promoting rich and purposeful classroom interactions, (f) fostering a creative and inquisitive learning opportunities, and (g) using assessment for learning. These items are not discipline specific, but operationalize teacher competency in observable actions, providing insights into how a competent teacher would perform in class. From a factor analysis of 76 observations of primary and secondary teachers teaching math, science, social studies, and language arts in the US, the study found that teachers' actions were distinct in three areas: facilitating high-level learning (d, e, f, g), designing and implementing coherent learning experiences $(a, b)$, and managing the learning environment (c; Marshall et al., 2016). These areas are not necessarily aligned with the normative categories of different types of knowledge and attitudes, indicating teacher competency shown in performance would look different from that measured through cognitive activities such as surveys or interviews (e.g., Vogt \& Rogalla, 2009). Thus, examining teacher competency requires a twoway process in which normative competency (top down) and competency in performance (bottom up) are examined simultaneously. 


\section{3}

\section{Methods}

\subsection{Self-Assessment Instrument Development}

In order to examine science teaching competency, initially we identified indicators in a top-down approach based on the literature and teacher education expert validation. Then, in a bottom-up process, we obtained feedback from a panel of in-service teachers to ensure that the indicators were realistic and represented competency in actual performance.

Teachers in South Korea have three types of responsibility: classroom teaching, student advising, and administration (Kang, 2013). The competency addressed in this study deals with classroom teaching responsibility in science, focusing on teacher competency needed for successful science teaching.

In their review of research on competency, Blömeke et al. (2015) suggest that "the definition of competence therefore has to start from an analysis of authentic job or societal situations and enumerate the tasks as well as the cognition, conation, affect, and motivation involved" (p. 5). The literature on teacher competency and the Korean TEPD framework both indicate that the professional task of classroom teaching consists of preparation, implementation, and improvement. Thus, our research team defined science teaching competency as "the ability to design, implement, and improve science lessons effectively by integrating knowledge and skills related to science teaching (subject matter knowledge, pedagogical content knowledge, and so on) and values and attitudes toward science teaching." Rooted in the contemporary Korean educational context, the premise of successful science teaching is defined as "a student-led inquiry class based on social constructivist learning theory, in other words, a class that can foster understanding of scientific knowledge and thinking and help students gain scientific attitudes and values that are stipulated in the Korean science curriculum." From this analysis of teaching tasks, we divided science teaching competency into three areas: science lesson preparation (SLP), science teaching performance (STP), and PD in science teaching (SPD). SLP is defined as "the ability to design science lessons through integration of the necessary knowledge, attitudes, and skills." STP is defined as "the ability to perform science teaching through integration of the necessary knowledge, attitudes, and skills." Finally, SPD is defined as "dispositions to participate in activities to improve science teaching." Given that competency manifests as a combination of knowledge, skills, and dispositions, we deliberately defined competency areas as teachers' abilities to perform in these three areas through integration of three competency elements: knowledge, 
skills, and dispositions. However, we recognize that the three areas weigh the three elements of competency differently. For example, SLP might give more weight to knowledge than skills, while STP might give more weight to skills than knowledge, and SPD might give more weight to dispositions than knowledge and skills.

Based on the definition of science teaching competency in relation to the premise of successful science teaching, we derived subcategories and indicators for each subcategory. In the process, we purposefully avoided overlapping competency elements between competency areas in order to make the self-assessment instrument short enough for teachers to use comfortably in their hectic schedules. For example, teachers' knowledge of science teaching methods might be used in both lesson preparation and performance. Our research team decided that teaching methods would be more salient in teaching actions than in lesson preparation. On the other hand, teachers' knowledge of students' interests or prior knowledge would be more salient in lesson preparation than in implementation. Through these decision-making processes we identified the most salient aspects of teaching competence in each area of competency and created indicators accordingly.

From the premise of successful science teaching, competent science teaching performance was envisioned as provision of an interactive, collaborative, student-centered, and experience-based learning opportunity. From this we extracted fundamental indicators of science teaching competency. We also applied the five science core competencies for students promoted in the national science curriculum because teachers are expected to facilitate students' development of those science competencies in class. The five core science competencies are scientific thinking, scientific inquiry, scientific problem solving, scientific communication, and scientific participation and lifelong learning (Korean Ministry of Education, 2015).

As a result, 34 indicators of teacher competence were initially devised. To validate the content of the indicators, we recruited a review panel that consisted of 15 science teacher education faculty from universities across the nation. We sent the panel members the list of indicators, along with definitions of science teaching competency and competency areas via email and then asked them to indicate the degree of their agreement on a 4-point scale. 1 represented strong disagreement, and 4 represented strong agreement. We also asked them to offer suggestions for revisions and additional indicators. The indicators that received a mean of 3.5 or above were retained, while others were revised, and we added additional indicators based on suggestions. We then sent the revised indictors to the panel for another round of validation. All but one indicator received a mean of 3.5 or above in the second round 
and were kept for this study, so with the additional suggestions 44 items were finalized. (Appendix A).

Once the indicators were validated by experts, we converted them into action phrases so that the frequency of teachers' activation of their ability could indicate the degree of competency. For example, one of the indicators, "ability to facilitate students' communication of scientific knowledge through scientific language and representations" was converted into the teacher self-assessment item, "in science teaching, I provide appropriate opportunities for students to use scientific terms and representations (graphs, tables, figures, etc.) effectively to represent science content." The underlying assumption of the conversion was that teacher competency could be inferred from performance, and we were interested in abilities activated in classroom teaching performance. Thus, in the self-assessment of science teaching competency, teachers were asked to reflect on the degree to which they performed certain actions. Teaching performance or frequency of standard actions would indicate teachers' competency, which could be mediated by teachers' skills grounded in knowledge and beliefs (Blömeke et al., 2015) or mediated by perceptions of specific teaching contexts grounded in knowledge and skills (Kang \& Wallace, 2005). Frequencies were given on a 5-point scale, with 1 indicating rarely and 5 indicating always.

A number of competency indicators were converted into multiple items in order to make the item specific to one type of action. For example, "ability to administer diagnostic, formative, and summative assessment based on assessment design" was converted into three items for each type of assessment including "in science class, I am performing diagnostic assessments effectively to identify the starting point of student learning."

Once the assessment items were developed, we recruited in-service teachers to ensure that the items were practical and could be read as intended. Twenty in-service teachers were recruited from teacher PD programs. Among them, four were primary teachers who specialized in science in their certification programs. The others were lower secondary school teachers (5) and upper secondary school teachers (11). These 16 secondary teachers' certifications were evenly distributed across physics, chemistry, biology, and earth science. The teachers were asked to complete the self-assessment individually while providing specific examples of actions for each item. The specific examples provided by the teachers were used to confirm whether they understood the intended meanings of the items. After completion, they were individually interviewed about (a) readability of each item and possible editing for making the items teacher friendly and (b) any additional feedback on the practicality of items. As a result, some items were rephrased to be more teacher friendly and one item, "providing opportunities for students to exchange ideas with students 
from other classes, other regions, or other countries," was eliminated because most teachers stated that the item described a rare instance. As a result, 54 selfassessment items were finalized (Appendix B).

\subsection{Data Collection}

The refined instrument was formatted in an online survey and then distributed to teachers across four cities and provinces of South Korea over the course of two weeks. While the teachers were able to respond to the items anonymously, the survey included questions about school level and years of teaching experience. Two hundred and ten teacher responses were collected. Among them, 73 were from primary teachers, 37 were from lower secondary school science teachers, and 100 were from upper secondary school science teachers. In terms of the teachers' years of teaching, 59 teachers had less than 5 years of teaching, 75 teachers had between 10 and 15 years of teaching, and 76 teachers had more than 15 years of teaching.

\subsection{Data Analysis}

For each competency area, reliability was checked and factor analysis was performed. Cronbach's $\alpha$ values of each area showed good to excellent internal consistency (o.882-0.968). In order to check whether the data was suited for factor analysis, we ran a Kaiser-Meyer-Olkin (KMO) test and Bartlett's test for sphericity on SPSS ver. 22. The resulting KMO value was sufficiently large (o.855-0.949), and Bartlett's test was significant in all areas (Table 1). Thus, the sampling for each area was adequate for factor analysis.

TABLE $1 \quad$ KMO and Bartlett's tests

\begin{tabular}{llcrr}
\hline $\begin{array}{l}\text { KMO measure of } \\
\text { sampling adequacy }\end{array}$ & $\begin{array}{l}\text { Preparation } \\
(17 \text { items })\end{array}$ & $\begin{array}{l}\text { Teaching } \\
(31 \text { items })\end{array}$ & $\begin{array}{l}\text { PD } \\
(7 \text { items })\end{array}$ \\
\hline $\begin{array}{l}\text { Bartlett's test of } \\
\text { sphericity }\end{array}$ & $\begin{array}{l}\text { Approx. } \\
\text { Chi-Square } \\
\text { Degree of freedom } \\
\text { Significance }\end{array}$ & 136 & .949 & .855 \\
\hline
\end{tabular}


In the factor analysis, we used varimax rotation and examined scree plot and eigenvalues of bigger than 1 to determine the least number of variables that could explain variances as much as possible.

After factors were identified, we analyzed differences of teacher competency across factors in each area in terms of teachers' years of teaching and school levels. In group comparisons, we used a non-parametric Kruskal-Wallis $\mathrm{H}$ test because group sizes were different, and group data on most factors failed to meet the normality assumption examined by skewness and kurtosis tests. As a post hoc analysis, we used the Kruskal-Wallis one-way ANOvA that examined differences in distributions across groups. In finding out which groups differed significantly, we used Bonferroni adjusted $p$-values to avoid Type I errors in multiple pairwise comparisons. Because Kruskal-Wallis test statistics use ranks transformed from continuous variables, we used the means of each group when interpreting the results.

Results

\subsection{Science Lesson Preparation Competency}

For the scale of SLP, we identified three factors (Table 2). The three factors had eigenvalues of more than 1 , and after three factors the scree plot leveled off. Communalities of all items were above .4 (0.446-0.725), and the cumulative amount of variance accounted by these three factors was $59.0 \%$. Thus, all items were deemed valid.

The three factors were distinguishable in terms of the content of lesson preparation. The first factor had 10 items that were mostly about consideration of the science learning environment, involving such things as lesson materials, ICT equipment, lab materials, and the general learning environment for student learning. The second factor had four items that were all about teachers' knowledge of teaching content in relation to science curriculum, involving things such as subject matter and inquiry. The third factor had three items that were about teachers' consideration of student cognition (Table 2).

\subsection{Science Teaching Performance Competency}

For the scale of STP, we identified four factors (Table 3). The four factors had eigenvalues of more than 1 , and scree plot started leveling off after the fourth factor. The cumulative amount of variance accounted for by the four factors was $65.1 \%$. Communalities of all items were above $.4(.448-.759)$. Thus, all items were deemed valid. 
TABLE 2 Rotated factor matrix of the SLP scale $(N=210$, varimax rotation $)$

\begin{tabular}{lllll}
\hline Code & Communality & & Factor loading & \\
& & & Learning & Teaching \\
& & environment & Student \\
& & & & content \\
& & 0.484 & 0.454 & 0.247 \\
\hline SLP 1.1 & 0.502 & 0.734 & 0.160 & 0.220 \\
SLP 1.2 & 0.613 & 0.178 & 0.728 & 0.043 \\
SLP 2.1 & 0.564 & 0.157 & 0.725 & 0.364 \\
SLP 2.2 & 0.683 & 0.141 & 0.719 & 0.245 \\
SLP 2.3 & 0.597 & 0.527 & 0.560 & 0.055 \\
SLP 2.4 & 0.595 & 0.620 & 0.235 & 0.425 \\
SLP 3.1 & 0.620 & 0.693 & 0.494 & -0.014 \\
SLP 3.2 & 0.725 & 0.700 & 0.347 & 0.069 \\
SLP 3.3 & 0.615 & 0.483 & 0.393 & 0.308 \\
SLP 3.4 & 0.482 & 0.318 & 0.212 & 0.739 \\
SLP 3.5 & 0.692 & 0.068 & 0.434 & 0.636 \\
SLP 3.6 & 0.597 & 0.361 & 0.122 & 0.741 \\
SLP 3.7 & 0.693 & 0.595 & 0.171 & 0.395 \\
SLP 3.8 & 0.539 & 0.587 & 0.164 & 0.342 \\
SLP 3.9 & 0.487 & 0.709 & 0.096 & 0.289 \\
SLP 4.1 & 0.595 & 0.521 & -0.007 & 0.417 \\
SLP 4.2 & 0.446 & & & \\
\hline & & & & \\
\hline
\end{tabular}

The four factors were distinguishable in terms of teaching goals. The first factor had 14 items, which were mostly about teaching science inquiry along with facilitating scientific thinking and fostering problem solving. Interestingly, this factor included an item about teachers' effective use of small-group activities that are typical to inquiry activities (STP1.CL5). The second factor had seven items that were about relating science to everyday lives. The third factor had six items that were about facilitating students' cognitive and generative engagement for productive learning. The fourth factor had all three assessment items (Table 3). 
TABLE 3 Rotated factor matrix of the STP scale $(N=210$, varimax rotation $)$

STP

Communality
Factor loading

Science Science and Productive Assessment inquiry everyday learning

\begin{tabular}{|c|c|c|c|c|c|}
\hline STP1.CL1 & 0.731 & 0.227 & 0.241 & 0.779 & 0.118 \\
\hline STP1.CL2 & 0.759 & $0.15^{2}$ & 0.373 & 0.719 & 0.283 \\
\hline $\mathrm{STP}_{1 . C L}$ & 0.646 & 0.146 & 0.379 & 0.640 & 0.267 \\
\hline STP1.CL4 & 0.448 & 0.420 & 0.194 & 0.453 & 0.169 \\
\hline $\mathrm{STP}_{1 . C L}$ & 0.677 & 0.613 & 0.004 & 0.340 & 0.431 \\
\hline STP1.CL6 & $0.45^{6}$ & 0.430 & 0.141 & 0.473 & 0.166 \\
\hline STP1.CL7 & 0.655 & 0.297 & 0.224 & 0.708 & 0.127 \\
\hline STP1.ST1 & 0.595 & 0.498 & 0.392 & 0.438 & 0.027 \\
\hline $\mathrm{STP}_{1 . S T} 2$ & 0.610 & 0.648 & 0.327 & 0.209 & 0.201 \\
\hline $\mathrm{STP}_{1 . S T} \mathrm{ST}_{3}$ & 0.687 & o. $65^{8}$ & 0.441 & 0.115 & 0.217 \\
\hline $\mathrm{STP}_{1 . S E} 1$ & 0.660 & 0.720 & 0.245 & 0.220 & 0.183 \\
\hline $\mathrm{STP}_{1 . S E} 2$ & 0.661 & 0.684 & 0.403 & 0.143 & o.o98 \\
\hline $\mathrm{STP}_{1 . S E} \mathrm{SE}_{3}$ & 0.738 & 0.790 & $0.25^{\circ}$ & 0.224 & 0.027 \\
\hline STP1.SE4 & o. 676 & 0.756 & 0.040 & 0.177 & 0.265 \\
\hline $\mathrm{STP}_{1} \mathrm{SC}_{1}$ & 0.520 & 0.126 & $0.5^{13}$ & 0.273 & 0.407 \\
\hline $\mathrm{STP}_{1 . S C}$ & 0.482 & 0.442 & 0.372 & 0.277 & 0.267 \\
\hline $\mathrm{STP}_{1 . S C_{3}}$ & 0.694 & 0.508 & 0.313 & 0.364 & $0.45^{2}$ \\
\hline $\mathrm{STP}_{1 . S C} 4$ & o.697 & 0.600 & 0.238 & 0.233 & 0.475 \\
\hline STP1.SP1 & 0.692 & 0.506 & 0.487 & 0.251 & 0.368 \\
\hline $\mathrm{STP}_{1 . S P} 2$ & 0.635 & 0.511 & 0.494 & 0.281 & 0.226 \\
\hline $\mathrm{STP}_{1 . S P}$ & o.659 & 0.490 & 0.514 & 0.222 & 0.325 \\
\hline $\mathrm{STP}_{1 . S P} 4$ & o.649 & 0.548 & 0.476 & $0.25^{2}$ & 0.242 \\
\hline STP1.SL1 & o.691 & 0.255 & 0.682 & 0.281 & 0.284 \\
\hline STP1.SL2 & 0.663 & 0.343 & 0.580 & 0.428 & $0.15^{8}$ \\
\hline $\mathrm{STP}_{1 . S L}$ & o.666 & 0.224 & 0.712 & 0.317 & 0.093 \\
\hline $\mathrm{STP}_{1 . S L} 4$ & 0.654 & 0.245 & 0.718 & 0.223 & 0.168 \\
\hline $\mathrm{STP}_{1 . S L} \mathrm{SL}_{5}$ & 0.719 & 0.337 & $0.65^{8}$ & 0.255 & 0.327 \\
\hline $\mathrm{STP}_{2.1}$ & 0.611 & 0.173 & 0.486 & 0.172 & 0.561 \\
\hline $\mathrm{STP}_{2.2}$ & 0.746 & 0.213 & 0.347 & 0.205 & 0.734 \\
\hline $\mathrm{STP}_{2.3}$ & ०.746 & 0.288 & 0.166 & 0.159 & 0.781 \\
\hline
\end{tabular}




\subsection{Science Teaching Professional Development}

For the scale of SPD, two factors had eigenvalue of more than 1, and after these two factors the scree plot began to level off. Communalities of all items were above .4 (0.614-0.799), and the cumulative amount of variance accounted by these two factors was $73.1 \%$. Thus, all items were deemed valid. The two factors were distinguishable in terms of mode of PD. The first factor had three items. All these items included modes of science PD recently provided and promoted in South Korea. All the forms of PD included in this factor require some degree of teacher initiative. The second factor had four items that included traditionally prevalent modes of PD (Table 4).

TABLE 4 Rotated factor matrix of the SPD scale $(N=210$, varimax rotation $)$

SPD Communality Factor loading

\begin{tabular}{llll} 
& & New mode & $\begin{array}{l}\text { Traditional } \\
\text { mode }\end{array}$ \\
\hline SPD1 & 0.775 & 0.144 & 0.868 \\
SPD2 & 0.774 & 0.200 & 0.857 \\
SPD3 & 0.614 & 0.460 & 0.634 \\
SPD4 & 0.718 & 0.745 & 0.405 \\
SPD5 & 0.752 & 0.832 & 0.243 \\
SPD6 & 0.799 & 0.884 & 0.135 \\
SPD7 & 0.685 & 0.515 & 0.648 \\
\hline
\end{tabular}

\subsection{Competency Differences}

Once factors were determined, we examined how teacher competency differed across factors in each area in terms of mean values. In the area of SLP, the means of teacher responses ranged from 3.82 to 4.09 . Teachers' responses demonstrated that in science lesson preparation, they tended to focus more on teaching content than consideration of learning environment and student cognition (Table 5). 
TABLE 5 Descriptive statistics of SLP area $(N=210)$

\begin{tabular}{lcll}
\hline SLP & No. of items & M(SD) & Cronbach \\
\hline Learning environment $\left(\mathrm{F}_{1}\right)$ & 10 & $3.92(\mathrm{o.63})$ & .892 \\
Teaching content $\left(\mathrm{F}_{2}\right)$ & 4 & $4.09(\mathrm{o}) 60)$ & .773 \\
Student cognition $\left(\mathrm{F}_{3}\right)$ & 3 & $3.87(0.71)$ & .753 \\
\hline
\end{tabular}

TABLE 6 Descriptive statistics of STP scale $(N=210)$

\begin{tabular}{lcll}
\hline STP & No. of items & M(SD) & Cronbach \\
\hline Science inquiry (F1) & 14 & $3.93(0.64)$ & .948 \\
Science \& everyday $\left(\mathrm{F}_{2}\right)$ & 7 & $3.91(0.70)$ & .908 \\
Productive learning $\left(\mathrm{F}_{3}\right)$ & 6 & $4.15(0.57)$ & .753 \\
Assessment $\left(\mathrm{F}_{4}\right)$ & 3 & $3.82(0.81)$ & .814 \\
\hline
\end{tabular}

TABLE 7 Descriptive statistics of SPD scale $(N=210)$

\begin{tabular}{lcll}
\hline SPD & No. of items & M(SD) & Cronbach \\
\hline New mode (F1) & 13 & $3 \cdot 33(1.07)$ & .839 \\
Traditional mode $\left(\mathrm{F}_{2}\right)$ & 7 & $3.93(0.74)$ & .841 \\
\hline
\end{tabular}

In the area of STP, the means of teacher responses ranged from 3.82 to 4.15 . In teaching actions, teacher responses demonstrated that they focused on fostering productive science learning $\left(\mathrm{F}_{3}\right)$ more than teaching science inquiry, relating science to everyday lives, and assessment (Table 6).

In the area of SPD, the means of teacher responses ranged from 3.33 to 3.93 . Teacher responses showed that teachers utilized traditional forms of PD more than recent forms (Table 7).

\subsection{Competency Differences between Teacher Groups}

Using the data on teachers' years of teaching and school levels, we examined group differences in teacher responses. Kruskal-Wallis tests showed that teachers with different years of teaching experience did not show much difference in their competency except in one factor: PD (SPD-F1). On the other hand, 


\begin{tabular}{|c|c|c|c|c|c|c|c|c|c|c|}
\hline \multirow[b]{2}{*}{ Factors } & & \multicolumn{3}{|l|}{ SLP } & \multicolumn{3}{|l|}{ STP } & \multicolumn{3}{|c|}{ SPD } \\
\hline & & $\mathbf{F}_{1}$ & $\mathrm{~F}_{2}$ & $\mathrm{~F}_{3}$ & $\mathrm{~F}_{1}$ & $\mathrm{~F}_{2}$ & $\mathrm{~F}_{3}$ & $\mathrm{~F}_{4}$ & $F_{1}$ & $\mathrm{~F}_{2}$ \\
\hline \multirow[t]{2}{*}{$\begin{array}{l}\text { Yrs. of } \\
\text { teaching }\end{array}$} & $\begin{array}{l}\text { Kruskal- } \\
\text { Wallis H }\end{array}$ & 3.123 & $3 \cdot 347$ & 2.735 & 3.937 & 2.248 & $4 \cdot 796$ & 1.679 & 11.242 & 2.474 \\
\hline & Asymp. Sig. & .210 & .188 & .253 & .140 & .325 & .091 & .432 & .004 & .290 \\
\hline \multirow[t]{2}{*}{$\begin{array}{l}\text { School } \\
\text { levels }\end{array}$} & $\begin{array}{l}\text { Kruskal- } \\
\text { Wallis H }\end{array}$ & 8.068 & .183 & 17.022 & 14.984 & 8.473 & $13.5^{22}$ & $13.95^{2}$ & 3.194 & .839 \\
\hline & Asymp. Sig. & 0.018 & .913 & .000 & .001 & .014 & .001 & .001 & .230 & .657 \\
\hline
\end{tabular}

a Shaded areas indicate significantly different factors at the significance level of .05.

TABLE 9 Kruskal-Wallis one-way ANOVA: Significant results only (groups of different yrs. of teaching)

Groups compared

SPD-F1

\begin{tabular}{lll} 
& MD $^{\mathrm{b}}$ & $\boldsymbol{p}^{\mathrm{c}}$ \\
\hline $1-2$ & -0.45 & .029 \\
$1-3$ & -0.60 & .004 \\
$2-3$ & -0.15 & 1.000 \\
\hline
\end{tabular}

a 1: teachers with less than 5 years of teaching; 2: teachers with between 5 and 15 years of teaching; 3 : teachers with more than 15 years of teaching.

b Mean difference.

c Significances were tested 2-sided. The significance level is .05.

teachers of different school levels demonstrated significant differences in six out of nine factors (Table 8).

In terms of difference between groups with different years of experience teaching, Kruskal-Wallis one-way ANOvA results showed that teachers with less than 5 years of experience showed significantly lower competency in the new mode of PD (SPD-F1) in comparison with the other two groups of teachers (Table 9). Relatively new teachers seemed to utilize new modes of PD significantly less than more experienced teachers. 
TABLE $10 \quad$ Kruskal-Wallis one-way ANOva: Significant results only (by school level)

\begin{tabular}{|c|c|c|c|c|c|c|c|c|c|c|c|c|}
\hline \multirow{2}{*}{$\begin{array}{l}\text { Group } \\
\text { compared }^{\mathrm{a}}\end{array}$} & \multicolumn{2}{|c|}{ SLP-F1 } & \multicolumn{2}{|c|}{ SLP-F 3} & \multicolumn{2}{|c|}{ STP-F1 } & \multicolumn{2}{|c|}{ STP-F2 } & \multicolumn{2}{|c|}{ STP-F 3} & \multicolumn{2}{|c|}{ STP-F4 } \\
\hline & $\mathbf{M D}^{\mathrm{b}}$ & $p^{c}$ & MD & $p$ & MD & $p$ & MD & $p$ & MD & $p$ & MD & $p$ \\
\hline P-L & 0.15 & .382 & $0.5^{0}$ & .000 & 0.32 & .018 & 0.30 & $.05^{8}$ & 0.34 & .004 & $0.5^{1}$ & .002 \\
\hline $\mathrm{P}-\mathrm{U}$ & 0.26 & .014 & -0.01 & 1.000 & 0.36 & .001 & 0.28 & .029 & 0.21 & .007 & 0.33 & .010 \\
\hline L-U & 0.11 & 1.00 & -0.51 & .000 & 0.04 & 1.00 & -0.02 & 1.00 & -0.13 & 1.00 & -0.18 & .724 \\
\hline
\end{tabular}

a U: upper secondary teacher group; L: lower secondary teacher group; P: primary school teacher group.

b Mean difference.

c Significances were based on two-sided test. The significance level is .05. Shaded areas indicate significantly different factors.

Teachers in different school levels showed many more differences, most of which resulted from primary teachers indicating higher competency in various factors than others, whereas lower and upper secondary teachers were mostly similar (Table 10). Primary teachers showed higher competency in creating an effective science learning environment (SLP-F1) and all factors of science teaching performance competency. Interestingly, upper secondary teachers demonstrated the highest competency in considering student cognition in lesson preparation (SLP-F3). It is notable that in the competency of PD, there was no difference between teachers of different school levels.

A self-assessment instrument for teachers to use in evaluating their competency in teaching for student competence in science was developed and validated. Drawing on the literature on teacher competency and science teacher education, we identified 44 indicators of science teaching competency in relation to the current Korean National Science Curriculum, from which 54 items for teachers' self-assessment were developed. From the analysis of data collected through online administration of the self-assessment instrument, we found that science teaching competency had various factors, and that some factors differed across school levels and years of teaching. Mean values of the responses were close to 4.0 , demonstrating that teachers enact competencyindicating performance frequently. One-way ANOva results showed that 
teachers with less than five years of teaching experience utilized traditional modes of PD significantly more than experienced teachers, and primary teachers perceived higher competency than secondary teachers.

The factors found in each area of science teaching competency and where teachers put their relative emphases provide substantial implications for science teacher PD designs. In preparing science lessons, teachers clearly distinguished between learning environment, teaching content, and student cognition. The responses also indicate that teachers considered teaching content more frequently than learning environment or student cognition, which includes such things as cognitive and motivational differences among students. This is a pattern that can be expected from a traditional teaching approach where teaching content has greater priority than learners or learning environment. Obviously, teachers consider teaching content more than who they are teaching or what kind of learning environment they want to prepare. Given that contemporary education aims at a student-centered approach, PD programs should address the emphasis on teaching content in science lesson preparation by introducing alternative approaches that are more student-centered.

The factors and relative emphases found in the teaching performance area call for careful interpretations. First of all, the four factors distinguished by teachers (factors shown in Appendix B) are different from those theoretically classified categories shown in indicators (Appendix A). We designed the indicators of teaching performance in terms of science learning environment, assessment, and teaching for five science competencies. Teachers distinguished learning environment from assessment just as was intended in the design, but they perceived teaching for science competencies differently from the design. All the items included in the factor of teaching for science inquiry are those traditionally emphasized in science inquiry teaching. Items of teaching for scientific thinking, scientific explanation, scientific communication, and scientific problem solving were all included, except those items that have been newly emphasized in recent science education literature (STP1.SC1 and STP1.SP3). The newly emphasized items were combined with the items for the scientific competency of "active participation and lifelong learning in science," which has also been newly introduced into the curriculum. Teachers' competency was slightly higher in the traditional inquiry factor $($ mean $=3.93)$ than teaching for the newly emphasized aspects of science learning $($ mean $=3.91)$. Similarly, in the area of science teaching PD, teachers showed lower competency in the new mode of PD $($ mean $=3.33)$ than in the traditional mode of PD $($ mean $=3.93)$. Therefore, in practice teacher competency is distinguishable in terms of how much teachers get used to certain tasks. In other words, teachers display higher competency as they exercise and get used to certain tasks. 
Among the factors of the teaching performance area, teachers rated the highest in fostering students' productive engagement by considering students' cognitive and motivational differences $($ mean $=4.15)$. This contrasts with the degree of teachers' consideration of student cognitive and motivational differences in lesson preparation $($ mean $=3.87$ ). Literally, in practice teachers consider students' cognition more during teaching than during planning. Meanwhile among the four factors of teaching performance, teachers showed the lowest competency in administrating assessment ( mean $=3.82)$. Given that the notion of "assessment for learning" (Wiliam, 2011) is not prevalent in the classroom, the result indicates that teachers assess students' learning progress less frequently. Thus, the idea that assessment is an integral part of instruction should be included in PD programs.

The differences in competency between teacher groups need further discussion. The only difference between relatively new (less than five years of experience) and experienced teachers is how much they were involved in new modes of PD. Given that new modes of PD require greater teacher initiative, it would be easier for experienced teachers than for new teachers to be involved in new modes of PD. On the other hand, the finding that no significant difference was found between less experienced and more experienced teachers in all the other factors needs further deliberation. In this study, teachers in general showed higher competency in more familiar aspects of teaching than in less familiar ones. This is in stark contrast to expert opinions shown in Alake-Tuenter et al.'s (2013) study, where experts indicated that there is less expectancy of some competency elements from novice teachers than experienced teachers. It is probable that classroom teaching competency might depend less on years of teaching or it may be possible to be quickly obtained to the same degree as experienced teachers. Further research on the trajectories of novice teachers gaining competency in classroom science teaching is necessary.

The competency in most factors shown by primary teachers being higher than that shown by secondary teachers might indicate differences in school context. This supposition looks more likely from the finding that upper secondary teachers, working in high schools where students' cognitive achievement is valued the highest, demonstrated the highest competency in considering student cognition during lesson preparation. Given that teacher competency is context dependent, teacher competency in general might be realized differently across school levels that have different types of students and different emphases on teaching goals. It is probable that a primary school context more readily allows for competency-focused learning. In other words, secondary school science teachers might employ traditional instruction more than primary teachers because of the emphasis on content knowledge. Further 
investigation with a larger sample and qualitative data would help test this supposition.

The findings of this study provide insight into PD design. The factors in which teachers demonstrated low competency indicate PD needs. For example, the newly introduced aspects of teaching and assessment should be addressed in $\mathrm{PD}$. If teachers are given the mean or median values to compare with their personal scores, individual teachers would be able to assess themselves to determine what they should develop further. Similarly, the low score shown in new modes of PD indicates that teachers need more opportunities and support to get used to the new modes of PD.

In this study, we did not examine how factors are related to each other. Understanding relationships between areas or between factors would elucidate effective ways to increase competency. For example, if factors in lesson preparation are highly related to some factors in teaching performance, PD in lesson preparation would be expected to increase teaching performance or vice versa. If factors within an area are highly related, increase of competency in one factor would help increase in the other related factors.

\section{6}

Implications

The instrument developed in this study is intended to be used by teachers as a self-assessment tool. If the instrument is used alongside outside observers such as teacher colleagues, the instrument can serve as a valued part of the conversation by pointing at specific aspects of teaching practices. Moreover, rather than simply identifying a teacher's current competency level, the instrument can serve as a tool to trace teachers' competency development. Also, the instrument can be easily modified for students to assess their science class. The information gathered from students might help teachers understand their teaching practices further.

To align with the current education climate in South Korea, as well as in other nations, the instrument developed in this study aims to move teacher evaluation practices away from a deficit view and toward a developmental view by supporting teachers' self-evaluation for professional growth. Further research on teacher development using the instrument and teachers' active involvement would help develop models of teacher competency development in competency-focused science teaching. 


\author{
Abbreviations \\ ICT \\ PCK \\ PD \\ SLP \\ SPD \\ STP \\ TEPD
}

\section{Ethics Approval and Consent to Participate}

The study was approved by the IR B of the first author's institution and online surveys were conducted anonymously after obtaining consent from the participants.

\section{About the Authors}

Nam-Hwa Kang is a professor at Korea National University of Education (KNUE), South Korea. Before she joined KNUE in 2012, she was an assistant professor at University of Nevada, Las Vegas, US, and an assistant and associate professor at Oregon State University, US. Her research centers on science teaching practices in relation to epistemic practices in science. She has published papers that address connections between science teacher beliefs about science learning, science inquiry, modelling in science, and scientific argumentation and teaching practices. Currently, she is the editor-in-chief of a journal, Innovation and Education, published by BMC (part of Springer Nature) and an associate editor of Asia-Pacific Science Education.

Hunsik Kang is a professor at Seoul National University of Education (SNUE), South Korea. Before he joined SNUE in 2016, he was an associate professor at Chuncheon National University of Education, South Korea. His research centers on teacher professionalism in science education and science-gifted education. He has published papers that address teachers' PCK, instructional strategies, and students' positive experiences with science in science education and science-gifted education. 
Seungho Maeng is an associate professor in the Department of Science Education at Seoul National University of Education (SNUE), South Korea. Seungho holds bachelor's and master's degrees in Earth science from Seoul National University and a doctoral degree in science education from Seoul National University. His research focuses on learning progressions on Earth science topics and analyses of reasoning practices in Earth science learning in terms of classroom discourse.

Jongwon Park is a professor at Chonnam National University (CNU), South Korea. His research area includes conceptual learning in physics, scientific creativity, and science teacher education. Currently, he is on the editorial board of Journal of Baltic Science Education and Science \& Education.

Eunyoung Jeong is a professor at Chonnam National University (CNU), South Korea. Before she joined CNU in 2010, she was a researcher at the Korea Institution for Curriculum and Evaluation (KICE) and a middle school science teacher. Her research centers on socio-scientific issues (ssi) education and science writing. She has published papers about developing evaluation instruments for scientific thinking ability using science writing, effect of programs for ssi education and flipped learning, and national curriculum implementation.

\section{References}

Ainley, J. and R. Carstens (2018). Teaching and Learning International Survey (TALIS) 2018 Conceptual Framework. OEcD Publishing: Paris. Retrieved from http://dx.doi .org/10.1787/799337c2-en.

Alake-Tuenter, E., Biemans, H. J. A., Tobi, H., \& Mulder, M. (2013). Inquiry-based science teaching competence of primary school teachers: A Delphi study. Teaching and Teacher Education, 35(3), 13-24. doi:10.1016/j.tate.2013.04.013.

Alake-Tuenter, E., Biemans, H. J. A., Tobi, H., Wals, A. E. J., Oosterheert, I., \& Mulder, M. (2012). Inquiry-based science education competencies of primary school teachers: A literature study and critical review of the American National Science Education Standards. International Journal of Science Education, 34(17), 26o9-2640. doi:10.108 o/o950o693.2012.669o76.

Blömeke, S., Gustafsson, J.-E., \& Shavelson, R. J. (2015). Beyond dichotomies: Competence viewed as a continuum. Zeitschrift Für Psychologie, 223(1), 3-13. doi:10.1027/2151-2604/aooo194.

Blömeke, S., \& Kaiser, G. (2017). Understanding the development of teachers' professional competencies as personally, situationally, and societally determined. 
In D. J. Clandinin \& J. Husu (Eds.), International handbook of research on teacher education (pp. 783-802). Thousand Oakes, CA: Sage.

Caena, F. (2014). Teacher competence frameworks in Europe: Policy-as-discourse and policy-as-practice. European Journal of Education, 49 (3), 311-331.

Chan, K. K. H., \& Hume, A. (2019). Toward a consensus model: Literature review of how science teachers' pedagogical content knowledge is investigated in empirical studies. In A. Hume, R. Cooper, \& A. Borowski (Eds.), Repositioning pedagogical content knowledge in teachers'knowledge for teaching science (pp. 3-76). Singapore: Springer Nature.

Danielson, C. (2007). Enhancing professional practice: A framework for teaching (2nd ed.).Alexandria, VA:Association forSupervision and Curriculum Development.

Depaepe, F., Verschaffel, L., \& Kelchtermans, G. (2013). Pedagogical content knowledge: A systematic review of the way in which the concept has pervaded mathematics educational research. Teaching and Teacher Education, 34, 12-25.

Fang, Z. (1996). A review of research on teacher beliefs and practices. Educational Research, 38(1), 47-65. doi:10.1080/0013188960380104.

Gess-Newsome, J., Taylor, J. A., Carlson, J., Gardner, A. L., Wilson, C. D., \& Stuhlsatz, M. A. M. (2019). Teacher pedagogical content knowledge, practice, and student achievement. International Journal of Science Education, 41(7), 944-963. doi:10.108 o/o950o693.2016.1265158.

Gonczi, A. (1994). Competency based assessment in the professions in Australia. Assessment in Education, 1(1), 27-44.

Guerriero, S. (Ed.). (2017). Pedagogical knowledge and the changing nature of the teaching profession. Paris: OECD Publishing. doi:10.1787/9789264270695-en.

Han, J., \& Yoon, J. (2012). An analysis of evaluation perspectives based on interested parties for evaluating science teachers' teaching ability in teacher expertise development evaluation. Journal of Research in Curriculum \& Instruction, 16, 941-960.

Kaiser, G., Blömeke, S., König, J., Busse, A., Döhrmann, M., \& Hoth, J. (2017). Professional competencies of (prospective) mathematics teachers - cognitive versus situated approaches. Educational Studies in Mathematics, 94(2), 161-182. doi:10.1007/ s10649-016-9713-8.

Kang, N.-H. (2013). Teacher evaluation policy development in South Korea. In M. Akiba (Ed.), Teacher reforms around the world: Implementations and outcomes (pp. 147177). Bingley, WA, UK: Emerald. doi:10.1108/S1479-3679(2013)ooooo19o12.

Kang, N.-H. (2017). Teacher evaluation reform in South Korea. In M. Akiba \& G. LeTendre (Eds.), International handbook of teacher quality and policy (pp. 542-556). New York: Routledge.

Kang, N.-H., \& Hong, M. (2008). Achieving excellence in teacher workforce and equity in learning opportunities in South Korea. Educational Researcher, 37(4), 200-207. doi:10.3102/oo13189Xo8319571. 
Kang, N.-H., \& Wallace, C. S. (2005). Secondary science teachers' use of laboratory activities: Linking epistemological beliefs, goals, and practices. Science Education, 89(1), 140-165. doi:10.1002/sce.20013.

Kind, V. (2009). Pedagogical content knowledge in science education: Perspectives and potential for progress. Studies in Science Education, 45(2), 169-204. doi:10.108o/o305726o9o3142285.

Korean Ministry of Education (2015). 2015 개정 과학과 교육과정 [2015 Revised Science Curriculum]. Sejong, Korea: Korean Ministry of Education.

Kulgemeyer, C., \& Riese, J. (2018). From professional knowledge to professional performance: The impact of $\mathrm{CK}$ and PCK on teaching quality in explaining situations. Journal of Research in Science Teaching, 55(10), 1393-1418. doi:10.1002/tea.21457.

Kunter, M., Klusmann, U., Baumert, J., Richter, D., Voss, T., \& Hachfeld, A. (2013). Professional competence of teachers: Effects on instructional quality and student development. Journal of Educational Psychology, 105(3), 805-820. doi:10.1037/a0032583.

Lave, J., \& Wenger, E. (1991). Situated learning: Legitimate peripheral participation. New York: Cambridge University Press.

Marshall, J. C., Smart, J., \& Alston, D. M. (2016). Development and validation of Teacher Intentionality of Practice Scale (TIPS): A measure to evaluate and scaffold teacher effectiveness. Teaching and Teacher Education, 59, 159-168. doi:10.1016/ j.tate.2016.05.007.

McDiarmid, G. W., \& Clevenger-Bright, M. (2008). Rethinking teacher capacity. In M. Cochran-Smith, S. Feiman-Nemser, \& D. J. McIntyre (Eds.), Handbook of research on teacher education: Enduring questions in changing contexts (3rd ed., pp. 134-156). New York: Routledge.

Mclaughlin, M. W., \& Talbert, J. (2001). Professional communities and works of high school teaching. Chicago: University of Chicago Press.

OECD [The Organization for Economic Cooperation and Development] (2005). The Definition and Selection of Key Competencies: Executive Summary. Retrieved from: http://www.oecd.org/pisa/35070367.pdf.

OECD [The Organization for Economic Cooperation and Development] (2013). Teachers for the 21st century: Using evaluation to improve teaching. Paris: OECD Publishing.

Pajares, M. F. (1992). Teachers' beliefs and educational research: Cleaning up a messy construct. Review of Educational Research, 62(3), 307-332. doi:10.3102/003465430 62003307.

Putney, L. G., \& Broughton, S. H. (2011). Developing collective classroom efficacy: The teacher's role as community organizer. Journal of Teacher Education, 62(1), 93-105. doi:10.1177/002248711038176o.

Rychen, D. S., \& Salganik, L. H. (Eds.). (2001). Defining and selecting key competencies. Ashland, $\mathrm{OH}$ : Hogrefe \& Huber. 
Seidel, T., \& Stürmer, K. (2014). Modeling and measuring the structure of professional vision in preservice teachers. American Educational Research Journal, 51(4), 739771. doi:10.1787/9789264193864-en.

Shulman, L. S. (1987). Knowledge and teaching: Foundations of the new reform. Harvard Educational Review, 57, 1-23.

Shulman, L. S. (1998). Theory, practice, and the education of professionals. The Elementary School Journal, 98(5), 511-526. doi:10.1086/461912.

Sorge, S., Stender, A., \& Neumann, K. (2019). The development of science teachers' professional competence. In A. Hume, R. Cooper, \& A. Borowski (Eds.), Repositioning pedagogical content knowledge in teachers' knowledge for teaching science (pp. 149164). Singapore: Springer Nature. doi:10.10o7/978-981-13-5898-2_6.

Voet, M., \& De Wever, B. (2016). History teachers' conceptions of inquiry-based learning, beliefs about the nature of history, and their relation to the classroom context. Teaching and Teacher Education, 55, 57-67. doi:10.1016/j.tate.2015.12.0o8.

Vogt, F., \& Rogalla, M. (2009). Developing adaptive teaching competency through coaching. Teaching and Teacher Education, 25(8), 1051-106o. doi:10.1016/j.tate.2009 .04.002.

Wiliam, D. (2011). What is assessment for learning? Studies in Educational Evaluation, 37(1), 3-14. doi:10.1016/j.stueduc.2011.03.001.

Windschitl, M. (2002). Framing constructivism in practice as the negotiation of dilemmas: An analysis of the conceptual, pedagogical, cultural, and political challenges facing teachers. Review of Educational Research, 72(2), 131-175. doi:10.3102/ oo346543072002131.

\section{Appendix A}

\section{Science Teaching Competence Indicators}

\section{Area 1. Science lesson preparation competence (SLP)}

SLP1. Ability to design an effective science learning environment (2 items)

1.1. Ability to apply students' cultural, environmental, and developmental features in lesson preparation

1.2. Ability to understand and form an effective physical environment for science learning

SLP2. Ability to understand science curriculum (3 items)

2.1. Ability to understand the science content in the science curriculum

2.2. Ability to understand science inquiry and competency elements in the science curriculum 
2.3. Ability to understand the goals and content of the national science curriculum and apply it to lesson design

SLP3. Ability to design effective science lessons (9 items)

3.1. Ability to design the student-centered lessons indicated by the national science curriculum

3.2. Ability to set learning objectives and design learning activities that can achieve the goals indicated by the national science curriculum

3.3. Ability to select and develop lesson materials that are appropriate for student levels and the curriculum

3.4. Ability to select and develop assessment appropriate for lesson objectives

3.5. Ability to plan science lessons in consideration of students' cognitive and affective differences

3.6. Ability to plan lessons in consideration of student prior knowledge and understandings

3.7. Ability to select and develop assessment for learning

3.8. Ability to utilize human and material resources in the community in lesson preparation

3.9. Ability to apply the results of student assessment to lesson preparation

SLP4. Ability to plan effective use of lesson materials (2 items)

4.1. Ability to plan effective use of lab equipment in science teaching

4.2. Ability to plan effective use of ICT in science teaching

Area 2. Science teaching performance competency (STP)

STP1. CL. Ability to create a constructivist learning environment (6 items)

1. Ability to form a trusting and respectful classroom culture

2. Ability to advance lessons based on students' cognitive and affective differences

3. Ability to guide students to construct their own explanations

4. Ability to facilitate students' group work

5. Ability to modify lessons in response to unexpected student reactions

6. Ability to explain science knowledge systematically considering students' abilities and levels

STP1. ST. Ability to foster students' scientific thinking competence (3 items)

1. Ability to facilitate students' logical and critical reasoning

2. Ability to foster students use of creativity

3. Ability to foster students' integrative thinking

STP1. SE. Ability to foster students' scientific inquiry competence (3 items)

1. Ability to facilitate students' scientific attitudes and participation in inquiry out of genuine curiosity 
2. Ability to facilitate students' applying inquiry skills to science inquiry activities

3. Ability to facilitate students' open-ended inquiry performance

STP1. SP. Ability to facilitate students' scientific problem-solving competence ( 3 items)

1. Ability to provide students with opportunities to find inquiry problems and goals

2. Ability to provide students with opportunities to solve everyday problems by applying scientific knowledge and principles

3. Ability to provide students with opportunities to reflect on inquiry processes

STP1. Sc. Ability to cultivate students' scientific communication competence ( 3 items)

1. Ability to facilitate students' communication of scientific knowledge through scientific language and representations

2. Ability to facilitate students' interactions and verbal communications with the teacher and other students

3. Ability to facilitate collaborative inquiry and problem solving

STP1. SL. Ability to cultivate students' scientific participation and lifelong learning competence ( 3 items)

1. Ability to facilitate students' interest in science learning and their recognition of science's utility

2. Ability to provide students with opportunities explore ethics in science and make decisions on science-related social issues

3. Ability to provide students with opportunities to explore careers related to science

STP2. Ability to assess science learning (2 items)

2.1. Ability to administer diagnostic, formative, and summative assessment based on assessment design

2.2. Ability to analyze assessment results with validity

Area 3. Science teaching professional development competency (SPD)

1. Efforts to improve the quality of science teaching through reflection on oneself or with colleagues

2. Efforts to collect student feedback on science teaching and utilize it to improve science teaching

3. Efforts to improve the quality of science teaching through participation in a variety of professional development programs

4. Efforts to improve the quality of science teaching through collaboration with various stakeholders

5. Ability to understand societal changes and make an effort to apply them to science teaching 


\section{Appendix B}

\section{Science Teaching Competence Self-Assessment Instrument (Items Arranged by Factors)}

\section{SLP. Science lesson preparation competency ( 17 items, 3 factors)}

\section{Factor 1. Consideration of science learning environment}

SLP1.1. When designing science lessons, I consider the cultural, environmental, and developmental characteristics of students.

SLP1.2. I understand and effectively create the environment necessary for science classes, such as the preparation of scientific teaching materials and tools and student seating arrangements.

SLP3.1. I design student-centered lessons that allow students construct their own science knowledge.

SLP3.2. I set learning objectives appropriate for the achievement standards presented in the curriculum and design learning activities accordingly.

SLP3.3. I design science lessons by selecting and developing appropriate materials for students' level and the science curriculum.

SLP3.4. I design an appropriate assessment to confirm the level of achievement of the learning objectives.

$\mathrm{SLP}_{3}$.8. When designing science lessons, I consider the human and material resources of the community where the school is located.

SLP3.9. When designing science lessons, I improve teaching and assessment methods by considering previous student evaluation results.

SLP4.1. I design science lessons so that I can effectively use experimental instruments and equipment.

SLP4.2. I design science lessons so that I can effectively use information and communication technology (ICT) such as smart devices and the internet.

\section{Factor 2. Understanding of science teaching content}

SLP2.1. I have a good understanding of the science content presented in the science curriculum.

SLP2.2. I have a good understanding of the science inquiry skills presented in the science curriculum.

SLP2.3. I have a good understanding of the core science competences presented in the science curriculum.

SLP2.4. When designing science lessons, I consider the goals and performance expectations presented in the science curriculum. 


\section{Factor 3. Consideration of student cognition}

$\mathrm{SLP}_{3.5}$. When designing science lessons, I consider individual differences in student cognition.

SLP3.6. When designing science lessons, I consider students' prior concepts and knowledge.

SLP3.7. When designing science lessons, I select or develop assessment for learning that can show students' changes and growth in the learning process and can provide feedback for them.

\section{STP. Science teaching performance competency ( 3 o items, 4 factors)}

\section{Factor 1. Teaching science inquiry}

STP1.CL5. I effectively use small-group activities in science teaching.

STP1.ST1. In science teaching, I provide appropriate opportunities for students to reason logically based on scientific evidence.

STP1.ST2. In science teaching, I provide appropriate opportunities for students to demonstrate scientific creativity.

STP1.ST3 In science teaching, I provide appropriate opportunities for students to utilize various areas of knowledge and skills in an integrative way.

STP1.SE1. In science teaching, I provide appropriate opportunities for students to observe and explore things with scientific attitudes and curiosity.

STP1.SE2. In science teaching, I encourage students to use scientific inquiry skills and knowledge in an integrative way so that they can effectively perform inquiry.

STP1.SE3. In science teaching, I provide appropriate opportunities for students to undertake self-directed scientific inquiry.

STP1.SE4. In science teaching, I provide appropriate opportunities for students to experience various types of exploration, such as experimentation, investigation, and discussion.

STP1.SC2. In science teaching, I provide appropriate opportunities for students to use scientific terms and representations (graphs, tables, figures, etc.) effectively to represent science content.

STP1.SC3. In science teaching, I provide appropriate opportunities for students to logically exchange their ideas and opinions and to understand each other in the content of science classes.

STP1.SC4. In science teaching, I provide appropriate opportunities for students to work together in solving inquiry problems.

STP1.SP1. In science teaching, I provide appropriate opportunities for students to find inquiry problems for themselves.

STP1.SP2. In science teaching, I provide appropriate opportunities for students to solve everyday problems by applying scientific principles.

STP1.SP4. In science teaching, I encourage students to reflect on their inquiry processes. 
Factor 2. Relating science to everyday life

STP1.SC1. In science teaching, I provide appropriate opportunities for students to understand scientific and technological information presented in various media such as broadcasting and the internet and to evaluate objectivity and scientific validity.

STP1.SP3. In science teaching, I provide appropriate opportunities for students to collect, analyze, select, and organize a variety of information related to scientific phenomena and solve problems in a scientific way.

STP1.SL1. In science teaching, I provide appropriate opportunities for students to be interested in science-related social issues and to make decisions reasonably.

STP1.SL2. In science teaching, I provide appropriate opportunities for students to recognize the joy of science learning and the usefulness of science.

STP1.SL3. In science teaching, I provide appropriate opportunities for students to explore ethical issues related to science and technology.

STP1.SL4. In science teaching, I provide appropriate opportunities for students to explore science-related careers.

STP1.SL5. In science teaching, I provide appropriate opportunities for students to explore the use of scientific knowledge in a variety of occupational fields.

\section{Factor 3. Facilitating productive engagement}

STP1.CL1. I create a science learning environment where students can participate with mutual respect and trust.

STP1.CL2. I operate science class in consideration of individual differences in cognitive aspects such as students' conceptual understanding and thinking levels.

STP1.CL3. I operate science class in consideration of individual differences in affective aspects such as students' motivation and interest.

STP1.CL4. I encourage students to explain science concepts and knowledge on their own.

STP1.CL6. When unexpected class situations happen that are different from planned lessons, I apply my plans flexibly.

STP1.CL7. I explain science content in consideration of the ability and the levels of students.

\section{Factor 4. Administrating assessment}

STP2.1. In science class, I perform diagnostic assessments effectively to identify the starting point of student learning.

STP2.2. In science class, I perform formative assessments effectively to evaluate students' academic achievement, improve teaching and learning, and provide feedback for students.

STP2.3. In science class, I perform summative assessments effectively to assess student achievement comprehensively. 
SPD. Science teaching professional development competency ( 7 items, 2 factors)

\section{Factor 1. New mode of SPD}

SPD4. I am actively involved in the teacher community (new science experiments development group, new assessment strategy development group, etc.) for the improvement of science teaching.

SPD5. I conduct academic research or action research to improve science teaching.

SPD6. I work with parents, school districts, and community members to improve science teaching.

\section{Factor 2. Traditional mode of SPD}

SPD1. I improve my science teaching by evaluating and reflecting on my science lesson designs and teaching activities by myself and/or with my fellow teachers.

SPD2. I collect student feedback on my science class and utilize it to improve my teaching.

SPD3. I actively participate in professional development programs, seminars, and workshops and apply them to improving my science teaching.

SPD7. I understand societal changes and requirements and explore ways to apply them to the content and methods of science class. 